\title{
Populism in political cartoons : caricatures of Nordic populist leaders
}

\author{
Herkman, Juha
}

2019

Herkman , J 2019 , ' Populism in political cartoons : caricatures of Nordic populist leaders ' , Popular communication : the international journal of media and culture , vol. 17 , no. 3 , pp. 252-267 . https://doi.org/10.1080/15405702.2019.1614183

http://hdl.handle.net/10138/321723

https://doi.org/10.1080/15405702.2019.1614183

acceptedVersion

Downloaded from Helda, University of Helsinki institutional repository.

This is an electronic reprint of the original article.

This reprint may differ from the original in pagination and typographic detail.

Please cite the original version. 


\title{
Populism in political cartoons: caricatures of Nordic populist leaders
}

\begin{abstract}
:
This article analyses political cartoons that depict contemporary populist politicians in Denmark, Finland and Sweden between 2005 and 2015, a period which focuses on the electoral successes of these movements. The hypothesis is that by analysing cartoons we can explore the underlying moral and normative confrontations linked to current political populism in the Nordic liberal democracies, which arose during the insurgent phase of the domestic right-wing parties. In total, 60 political cartoons are analysed by means of content categorisation and visual semiotics. The most popular caricatures in the cartoons depicted the leaders of the populist parties, while the most common signifiers linked the populism in the cartoons explicitly to fascism, Nazism, nativism and racism. In this, the cartoons differed from news journalism, reflecting the specific role of cartoons in public opinion discourse and indicating special characteristics that derive from particular political contexts and also the cartoonists' own perspectives.
\end{abstract}

Keywords: populism, political cartoons, Nordic countries, visual semiotics, life cycle model, moral order

Political cartoons have long played a visible role in the history of newspapers and political satire, although their political importance has often been seen as rather marginal. Thus, cartoons, employing humour as their main weapon, may be mocking and satirical but remain quite harmless from the point of view of political power. As many theorists have argued, humour often works as a societal "safety valve", allowing the discharge of anger and discontent in a way that does not harm but actually strengthens social order (see Mulkay, 1988).

Nevertheless, there have been several occasions in the history of political cartoons that have resulted in real political effects. The most recent and perhaps best known were the publishing of twelve cartoons depicting the Islamic Prophet Mohammad in the Danish newspaper Jyllands-Posten 
on 30 September 2005 and the cumulative effect of the cartoons that led to the terrorist massacre at the editorial office of Charlie Hebdo in Paris in 2015. The issues surrounding them emerged as global media events that caused riots in many countries and a violent thirst for revenge among fundamental Islamists and their opponents as well as large-scale debates over the freedom and responsibility of speech in Western societies (see e.g. Eide et al., 2008; Hollis-Touré, 2016). In the course of history, authoritarian and totalitarian regimes have also censored and banned political cartoons and even persecuted political cartoonists.

The power of cartoons possibly derives from the effectiveness of a caricature that visually represents features, sentiments and ideas that would require pages of literary explanations (Berger, 1995, p. 144). Hence, political cartoons can bring to the fore underlying tendencies and common sense ideas of the political moment (Abraham, 2009, p. 119; Greenberg, 2002, p. 181; Hess \& Northrop, 2011, p. 20). As such, cartoons provide a form of opinion discourse, which has been, according to Wiid et al. (2011, p. 138), approached through "weak" and "strong" theories. In weak theories it is believed that the cartoons can reveal the public attitudes of the time, but strong theories argue that cartoons themselves "actually persuade and shape public attitudes, intentions and behaviours" (ibid.).

It is often difficult to empirically prove the actual effects of specific cartoons, if there are no such devastating and explicit consequences as in the Mohammad cartoon or the Charlie Hebdo cases (cf. Hess \& Northrop, 2011, pp. 8-10). Therefore, this study applies rather the weak version of opinion discourse theory. It is argued here that by analysing cartoons depicting caricatures of contemporary populist leaders and agendas we can explore the underlying moral and normative confrontations linked to today's political populism in the Nordic liberal democracies.

Historically, political cartoons have had an established role as part of the editorial opinion discourse of newspapers. As printed newspapers have faced serious troubles during the last decades and many of them have even ceased to exist, the significance of political cartoons may have declined. 
However, Bal (2011, p. 135) reminds us that the Internet has "provided substantial and, importantly, highly accessible platforms and channels for professional and amateur cartoonists". In this sense, one may even argue that political cartoons are enjoying a renaissance in the twenty-first century, "free of the many constraints of traditional media" (ibid.).

At the same time, in many European liberal democracies populist radical right-wing movements emphasising a nationalist or nativist approach have raised their heads, meaning non-native groups and other minorities are marginalised or face even hostile attitudes towards them (e.g. Mudde, 2007, p. 19). As the populists have gained success and entered into parliaments and governing cabinets, the media attention on them has increased (see Mazzoleni et al., 2003; Anonymized, 2017a) and their leading representatives have become regular characters in cartoons that reflect contemporary political environments and moral controversies.

However, as mainstream news media commonly represents democratic values, they are rather critical or even hostile to anti-immigration, xenophobic or racist right-wing populist rhetoric (see Herkman, 2016). Therefore, radical right-wing movements often use new communication technologies such as blogs and social media sites to bypass journalistic control and form their own identity (e.g. Krämer, 2017; Engesser et al., 2017). It is thus also probable that the political cartoons published by the mainstream news media are quite different to those images published and circulated in social media platforms favoured by the supporters of right-wing populist movements.

This article analyses political cartoons published in mainstream news media, depicting contemporary populist right-wing movements and their leaders in Denmark, Finland and Sweden between 2005 and 2015. Since populism has been said to be a rather vague concept (e.g. Canovan, 1999; Taggart, 2000), the main objective is to explore the significations of populism made by political cartoons when they caricature populist politicians. Therefore, the emphasis here is on studying the caricatures that capture politicians commonly called populists, meaning the leading figures of so-called contemporary populist parties. The focus here is on the cartoons published 
during the insurgent phases of those parties in the early 21 st century. The research questions of the study are:

RQ1. Whose caricatures were often portrayed in the political cartoons that interpreted the rise of the Nordic right-wing populist movements of the early 21 st century?

RQ2. What kind of meanings do the political cartoons emphasise with regard to populism in the period when the Nordic populist parties became successful?

RQ3. How is populism visually signified in political cartoons?

RQ4. What do the differences between the cartoons reveal about the contextual variations of the moral order in the Nordic countries?

The main method of study is visual semiotics, despite research questions one and two being first answered by the classification of the cartoons. Before the cartoons are classified, the definitions of populism and the context of Nordic populism are briefly introduced.

\section{Theories of populism}

The term "populism" derives from Latin noun "populus" meaning "the people". Therefore, it is possible to understand it in a positive light with regard to the democratic process (Canovan, 1999; Mudde \& Kaltwasser, 2012). However, in political discourse populism is most commonly used pejoratively as it carries negative rather than positive connotations (Canovan, 2005; Bale et al., 2011; Herkman, 2016). In its simplest interpretation, populism refers to a political style or rhetoric that appeals to the people by simplifying political issues and exacerbating others. Thus, "populist" refers to a politician who promises much to gain popularity but who is unable to keep promises. Nevertheless, this definition of populism as merely being a political style has been thought to be too simple because a populist antagonist almost always sets up confrontations of "us" - meaning "the 
people" - versus "them"; groups in the population - elites, immigrants, minorities - that are not identified as "the people" (see Jagers \& Walgrave, 2006, pp. 336-337; Mazzoleni, 2014, p. 46).

Therefore, an ideological dimension of populism has been considered. However, as Stanley (2008) has put it, ideology in populism has been described as "thin" since no coherent or single ideological core can be found in populism. Historically, populism has been linked to very different ideologies and movements - be they right- or left-wing, democratic or authoritarian, urban or agrarian (Taggart, 2000, p. 1). Laclau (2005) has emphasised in his theorisations that populism is a logic of political identity formation rather than a strict ideology, thus it can, as such, link contingently, i.e. "articulate" very different ideologies and approaches, which may even be in conflict or contradict one another depending on the specific context and political conjuncture. Thus, the power of populism actually lies in its "chameleonic" nature - in its capability to incorporate different kinds of political ideologies (Taggart, 2000; Stanley, 2008).

Nevertheless, even if not all contemporary populist movements can be defined as right-wing, in twenty-first century European discussions populism has most commonly been linked to radical right-wing movements that emphasise nationalist and even nativist rhetoric (see Mazzoleni et al., 2003; Mudde, 2007; Rydgren, 2010). "Nativism” for Mudde (2007, p. 19) means “an ideology, which holds that states should be inhabited exclusively by members of the native group ('the nation') and that non-native elements (persons and ideas) are fundamentally threatening to the homogenous nation-state". Mudde's (2007, p. 23) definition of populism as "a thin-centred ideology that considers society to be ultimately separated into two homogeneous and antagonistic groups, 'the pure people' and 'the corrupt elite"' has been widely adopted by academic scholars, even though some criticism - especially of its ideological emphasis - has been made (e.g. Aslanidis, 2016; Moffit \& Tormey, 2014).

Mazzoleni and his colleagues concluded their comparative study of the relationship between the media and populist movements with a life cycle model, in which "the insurgent phase" indicated 
that the increasing success of the movement was characterized by intense media attention (Stewart et al., 2003, pp. 219-220). Indeed, several studies have demonstrated a positive relationship between an increase in media attention and the success of populist movements and their leaders (e.g. Boomgaarden \& Vliegenthart 2007; Roodjuin 2014), although there are also studies which challenge that argument (e.g. Pauwels, 2010; Bos \& Brants, 2014). Anonymized's (2017a) study shows that the life cycle model fits the Nordic context to some extent, but contextual differences can also be found between the countries. Even if the relationship between the media and populism has been extensively studied in the Nordic context and the history of political cartoons is well researched and various case studies have been conducted (e.g. Hess \& Northrop, 2011; Kuipers, 2011; Wiid et al., 2011; Van Hecke, 2017), the significations of populism found in political cartoons has not been previously studied.

\section{Contemporary populists in Denmark, Finland and Sweden}

The Nordic countries are typical representatives of consensual multiparty democracies based on the welfare state model. Paloheimo (2012, p. 329) has emphasised that populist parties have been especially successful in countries traditionally reliant on consensus in policy-making because the establishment is easily labelled a "corrupt elite" by populists. Successful populist movements appeared in Denmark, Norway and Finland already in the 1970s. However, in general, the Nordic parties garnered widespread success after they promoted intense criticism of immigration in the early 2000s, while a successful populist party only appeared in Sweden in the 2010s when the nationalist Sweden Democrats gained seats in parliament; the New Democracy movement of the 1990s was a short-lived success (Fryklund, 2015).

Table 1. The contemporary Nordic right-wing populist parties in Denmark, Finland and Sweden 


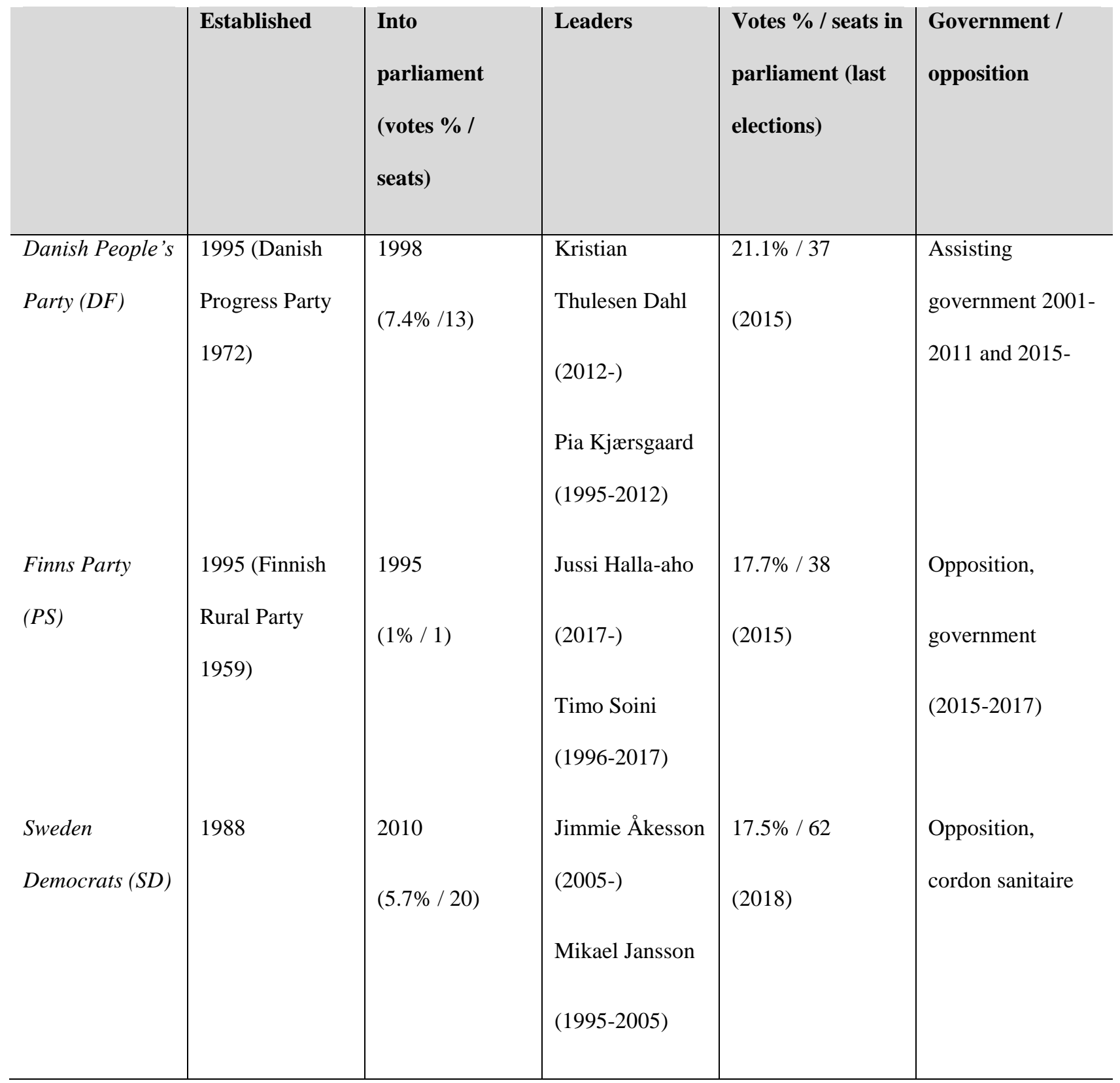

This study focuses on contemporary right-wing populist political parties in three Nordic countries (see Table 1): Danish People's Party (Dansk Folkeparti, DF), The Finns Party (Perussuomalaiset, PS) and Sweden Democrats (Sverigedemokraterna, SD). Due to its long history in the domestic party field and its libertarian orientation the Norwegian Progress Party (Fremskrittspartiet, FrP) has been excluded from the analysis because it represents a slightly different case, even if the party shares an anti-immigration programme with other European and Nordic radical right-wing parties. 
FrP also resembles traditional conservative rightist parties and is thus not always eagerly identified as a right-wing populist movement (see Jungar \& Jupskås, 2014; Allern, 2013).

Both DF and PS were established in 1995 from the remnants of the successful populist parties of the 1970s. They entered their political arenas as minor populist movements, but during the 21 st century they have become established political players. DF assisted the conservative governments of Denmark between 2001 and 2011 and since the 2015 general election, when it became the second largest party. PS was a minor player before the "big bang elections" of 2011 (Arter, 2012), in which the party became the third largest. In the 2015 elections, PS lost votes but came second, joining the governing cabinet for the first time in its history. However, PS split into two at its party conference in 2017 when voting the strong immigration critic Jussi Halla-aho and his followers into leadership positions. The story of SD is different: thus far the party has been excluded from political decisionmaking due to its National Socialist movement background (see Baas, 2014), even though it gained 17.5 percent of the vote in the latest Swedish general election. In all three countries, the success of populist parties has challenged traditional consensus politics and the status quo of the party system (see Arter, 2012).

In general, populism in the Nordic countries has not been regarded as offensive in style as it is in countries where politics is more confrontational (Widfeldt, 2010, p. 179). According to the European Social Survey (ESS), the supporters of the Nordic populist parties are quite different to extremist populist movements, because they rely on a democratic society and want to be integrated into it (Mesežnikov et al., 2008; Paloheimo, 2012, p. 337). However, even if there are different domestic emphases, nationalistic approaches and criticising immigration have been central issues in their programmes and in the public rhetoric of all three parties, which links them to other radical right-wing parties in Europe (see Jungar \& Jupskås, 2014).

The popularity of these parties in the 21 st century's elections has mainly relied on their charismatic party leaders, who have also received significant media attention. Jimmie Åkesson has tried to 
change the image of SD from that of a National Socialist movement towards being a serious political party and also led the party into Sweden's parliament in the 2010s. However, some more radical members of the party, for example, Erik Almqvist, Kent Ekeroth and Christian Westling, have also become media figures. In Denmark, Pia Kjærsgaard was the original leader and most popular public figure of DF, but other leading members of the party, such as its current party leader Kristian Thulesen Dahl and the very popular Member of European Parliament, Morten Messerschmidt, have gained considerable media attention. In Finland, Timo Soini led PS for 20 years and has been by far the most popular public figure of the party, but some radical MP's, such as Jussi Halla-aho (current PS leader), Olli Immonen and Teuvo Hakkarainen, have also been the subject of intense media scrutiny. Consequently, all the persons mentioned above have also been depicted in political cartoons.

\section{Methods and materials}

The data used for the analysis contains 60 political cartoons - 20 from each country - portraying politicians from the contemporary populist parties of Sweden, Finland and Denmark. The materials were collected from the domestic media archives from which the political cartoons and caricatures published between 2005 and 2015 were mapped and the cartoons' links to SD, PS and DF were examined. Digital archives are commonly text based and images are often excluded from their search engines and procedures. Therefore, it was practically impossible to make any statistically reliable searches into the cartoons and the material was gathered rather via the "snow-ball method" of exploring key cartoonists and their work, meaning first the mapping of the cartoonists who had targeted domestic populist politicians in their work and then a more detailed analysis of their cartoons.

In Denmark, printed collections of political cartoons were also examined during the search process because Danish printed newspapers have separate archives for their digital formats. In Sweden, the sample was obtained by using the newsmap.se platform because other search procedures seemed 
rather unsatisfactory. The Finnish sample is based on a larger study of political cartoons linked to PS in which 201 systematically sampled cartoons were included in a statistical analysis (Anonymized, 2017b). A native research assistant with a good track record in media studies and politics collected material from Denmark. In Sweden and Finland research assistants helped in the mapping of cartoons, but I gathered the actual data after these pre-inquiries. For reasons of clarity, the focus was on cartoons that included explicit caricatures or portraits of populist party members, other types of cartoons were excluded because any other sample definition would have been rather unclear.

Although the search period is between 2005 and 2015, the actual sample period varies between the countries due to their domestic populist parties' differing histories. The cartoons were collected from the period of the relevant party's "insurgent phase". In Sweden this means year 2010 when SD received 5.7 percent of the vote in the parliamentary election, surpassing the four percent threshold value for a seat in parliament. In Finland PS received 19.1 percent of the votes in the 2011 "big bang" parliamentary election and became the third largest party. These were the turning points when the parties also became visible in mainstream political cartoons. After their electoral success, some party members of SD and PS caused nationwide public scandals due to racist speech and behaviour. In Sweden the largest media event was 2012's “iron bar scandal”, while Jussi Hallaaho's court case, 2008-2012, and Olli Immonen's Facebook scandal in 2015 were the most striking events in Finland (see Anonymized 2017c). In Denmark, DF had already lived through its insurgent phase earlier in the 2000s but faced its most wide-ranging scandal in 2007 when the party's MP Morten Messerschmidt was alleged to have made a Nazi salute and sung Nazi songs in Copenhagen's Tivoli. Thus, most of the sample cartoons in Sweden are from the period of 20102014, in Finland from 2011-2015 and in Denmark from 2005-2010.

In all countries, four or more artists were included in the sample in order to cover a variety of styles and publications. In Denmark, Jens Hage (e.g. Kristeligt Dagblad), Morten Ingemann (Ekstra 
Bladet) and Roald Als (Politiken) drew most of the sample cartoons, but Anne-Mette Steen Petersen (Politiken), Niels Thomsen, Anette Carlsen (Jyllands-Posten) and Niels Bo Bojesen (JyllandsPosten) are all represented by one cartoon. For the Swedish sample, most cartoons are drawn by Jan-Erik Ander, who is one of the founder members of the Kreabs information company and who has published political cartoons in such Swedish dailies as Norrköpings Tidningar and Svenska Dagbladet. In addition, cartoons by Riber Hansson, Leif Zetterling and Lennart Moberg are included. The first two are distinguished cartoonists, having published their drawings in many Swedish and European forums and Moberg has a background as a popular comic book artist who has recently enlarged his repertoire from comics to political satire.

The Finnish material consist of cartoons drawn by four nationally famous cartoonists (five pictures from each of them). Henrik Karlsson draws cartoons for Helsingin Sanomat, the largest Finnish quality daily newspaper, three times a week. Timo Mäkelä aka "Timppa" publishes his drawings in Ilta-Sanomat, the largest popular paper of Finland, two times a week, and Jari Elsilä publishes his cartoons three to five times a week in Kaleva, the largest regional newspaper in Northern Finland. Ville Ranta draws cartoons for Kirkko \& Kaupunki, which is a weekly magazine published by the Evangelical Lutheran Church of Finland. Ranta is famous for his highly provocative cartoons and, for example, he took part in the debates over the Muhammad cartoons through his own drawings in 2006. Thus, except for two Danish pictures, all the cartoons studied have been published in mainstream newspapers or periodicals.

The cartoons were first categorised so that the main target persons of the caricatures and the primary significations of populism in each country could be classified (cf. Rose, 2001, pp. 54-67). The sampling of the study here does not allow us to make any statistically reliable content analysis of Nordic "cartoon imagery". Nevertheless, it is plausible that the categorisation of the caricatures and the main themes in the sample cartoons reveal common tendencies in the portrayal of Nordic populist politicians in cartoons during the insurgent phase of populist parties. After categorisation, 
the cartoons' visual semiotics were analysed to find out how the cartoons try to convince their readers of their highlighted meanings or significations regarding the populist actors (see Moriarty, 2005).

\section{Caricatures and main significations in the cartoons}

It is not a surprise that the party leaders of the domestic populist parties are by far the most popular figures represented in political cartoons linked to the populist movements. As part of the press publicity, political cartoons repeat the patterns commonly set in political news, in which leading political figures such as Presidents, Prime Ministers, and other key Ministers and party leaders dominate (cf. Bos et al., 2011). It is plausible, that in a statistically reliable sample, the share of populist leader caricatures could even be much higher than in this kind of selected sample, in which more variation in the caricatured figures was pursued on purpose (cf. Anonymized, 2017b). However, the cartoonists also draw caricatures of those members of populist parties who become public figures due to their provocative statements or behaviour, thus creating delicious material for political satire.

In the Danish cartoons included in the sample, the original leader of DF, Pia Kjærsgaard, was the most popular figure portrayed and featured in 11 caricatures, whereas the current leader, Kristian Thulesen Dahl, was depicted in five caricatures (see Table 2). However, some other members of the party were also portrayed in political cartoons, for example, the current MEP Morten Messerschmidt features in three caricatures and has been a much satirised public figure in Denmark for years due to several nativist provocations he has made thus far in his political career (see Bruun, 2012, pp. 165-166). In Finland, the long-term party leader of PS, Timo Soini, was depicted in 20 caricatures, but the party's current leader since 2017 and MEP Jussi Halla-aho and other party members were also portrayed in several cartoons between 2011 and 2015 because they have used more explicit racist and nativist rhetoric than Soini. Ville Ranta has especially depicted a heterogeneous group of characters in his cartoons, whereas other cartoonists have mostly focused 
on caricaturing the party leader (Anonymized, 2017b). In Sweden, Jimmie Åkesson was clearly the most popular figure to caricature but Mattias Karlsson was also caricatured twice in the sample during the period when he acted as party leader in 2014 and 2015. However, as the party has reached a more established status in the political field, some of its members - such as the Deputy Speaker of Parliament Björn Olof Sönder - have been portrayed in political caricatures.

Table 2. Caricatures and the significations of populism in the political cartoons $(n=60)$

\begin{tabular}{|c|c|c|c|c|c|c|c|c|c|c|}
\hline & $\begin{array}{l}\text { Party } \\
\text { leader }\end{array}$ & $\begin{array}{l}\text { Other } \\
\text { member }\end{array}$ & $\begin{array}{l}\text { Fascism } \\
\text { / Nazism }\end{array}$ & $\begin{array}{l}\text { Racism / } \\
\text { nativism }\end{array}$ & Success & Populism & $\begin{array}{l}\text { Caricature } \\
\text { figure }\end{array}$ & - & $+/-$ & + \\
\hline Denmark & 17 & 6 & 5 & 9 & - & 5 & $1(2)$ & 10 & 10 & - \\
\hline Finland & 20 & 18 & 2 & 5 & 6 & 7 & - & 13 & 3 & 4 \\
\hline Sweden & $13(2)$ & 7 & $3(2)$ & 2 & $5(1)$ & 5 & $3(1)$ & 10 & 8 & 2 \\
\hline Total & 50 & 31 & 10 & 16 & $11(1)$ & 17 & $4(3)$ & 33 & 21 & 6 \\
\hline
\end{tabular}

Herkman (2016) analysed the meanings given to populism in the Nordic press in the beginning of the 2010s and discovered that populism, when explicitly mentioned, was most often linked to domestic populist parties or radical right-wing populism in Europe. Consequently, according to his analysis, the most common journalistic frames linked populism to nationalist and nativist ideologies, emphasising either a nostalgic yearning for a "lost national heartland" (Taggart, 2000) or the hostile exclusion of immigrants and other non-native groups of people from the population (Mudde, 2007). However, populism was commonly linked to empty political rhetoric (Bale et al., 2011) and it was also framed more neutrally as a political movement or even positively as an indicator of "the people's will” in some Swedish and Finnish newspaper articles.

Similarities can be found between these framings and the signifiers depicting populism in political cartoons but because political cartoons create such a different form of representation compared to 
newspaper articles, the significations of populism also varied. In political cartoons, populism cannot be discussed on an abstract level but is visualised through caricatures of the portrayed characters and their actions. Therefore, populist characters were depicted with various identifiable features or signifiers that linked them to nationalist and nativist ideologies and those signifiers were more specific and presented in a more pointed, i.e. caricatured, way than in news discourse. This became particularly evident through several direct references to fascism and Nazism in political cartoons that, in turn, were almost absent in news discourse.

In addition to references to fascism and Nazism, nativist ideology was commonly represented in political cartoons by populist characters' xenophobic or hostile behaviour towards non-native groups. Together, these two visualisations - references to fascism and Nazism and references to racism and nativism - were the most popular meanings associated with populist characters in the sample cartoons (see Table 2). However, the actions termed "populism" here as well as the depictions of the populist parties' successes were common in political cartoons. The former category refers to cartoons in which populist characters were portrayed as demagogic politicians who do not conduct responsible politics. Populist characters classified in the latter category were shown as triumphant in the success of their party in the cartoons, often while leaders of other (more mainstream) parties marvelled at their success. A few cartoons were also simply traditional political caricatures of populist figures.

The aim of political cartoons is to satirise and therefore to criticise politics and politicians (Hess \& Northrop, 2011), meaning that most of the sample cartoons portrayed the politicians in a critical light. However, the cartoons were not uniform in their stance towards the populist politicians and parties, which partly derives from the incongruent nature of humour (see Palmer, 1994). Nevertheless, only a few of the cartoons depicting the success of the populist movements were positive in their representations. However, in this, the portrayals of populist politicians are not different to representations of other (more mainstream) politicians, because - as mentioned - 
political cartoons tend to criticise all the politicians they caricature. Thus, what is different are the visual signifiers used in this criticism.

\section{Visual semiotics of the cartoons}

As the main topics of the cartoons demonstrate, such signifiers of right-wing populism as fascism and Nazism were common in Denmark and in Sweden, while signifiers of nativism and racism were common in Denmark and in Finland. The signifiers of fascism and Nazism included such features as swastikas, (Nazi) uniforms and caps as well as "Sieg Heil”or Nazi salutes and "Hitler moustaches". These signifiers were crystallised, for example, in the Danish art collective Schwimmelmann's cartoon in which Pia Kjærsgaard and Morten Messerschmidt were depicted as paper dolls or jumping jacks dressed in Nazi uniforms and cap, raising their arms to give Nazi salutes. The cartoon was part of the collective's campaign against DF in 2009 explicitly demonstrating the public struggle over imaginaries linked to Danish populism (see Image 1). Kjærsgaard and Thulesen Dahl are also wearing uniforms in two Jens Hage's cartoons, and Messerschmidt has a Hitler moustache in one caricature imitating an election poster. In one cartoon published on 14 December 2008 in Ekstra Bladet, a Danish pastor and MP of DF, Søren Krarup, whips an immigrant with Hitler's Mein Kampf.

\section{Image 1}

In Swedish cartoons, the signifiers of Nazism are less explicitly linked to the caricatured persons than to the party and are more likely to signify the ideological background of the SD as a National Socialist movement. The most common (and the only) signifier of Nazism in these cartoons was the swastika. The use of the swastika made clear that SD is not an ordinary party but has an extremist movement background. The message was often emphasised by accompanying references to the socalled "iron-bar scandal" in which three key members of SD in 2010 - Erik Almqvist, Kent Ekeroth and Christian Westling - insulted comedian Soran Ismail and others by making racist and sexist 
comments; they also armed themselves with iron-bars taken from scaffolding in Stockholm city centre. The scandal burst out almost two years later in 2012 when popular paper Expressen published video-clips of the original incident (see Anonymized, 2017c).

After the scandal, Jan-Erik Ander drew a cartoon in which SD's leader Jimmie Åkesson speaks on a shaky stage constructed from a spirit bottles ("helrör") and iron-bars ("järnrör") tied to each other in swastika form (see Image 2). The same motif was repeated in Ander's cartoon two years later, in which Björn Olof Sönder rope danced with a unicycle that contains a swastika in its wheel. Sönder tries to balance himself by holding an iron-bar in his left hand and a chairman's gavel in his right hand.

\section{Image 2}

In Finnish cartoons, the use of signifiers linked to Nazism or Fascism was less striking than in Swedish and Danish cartoons, even though, signifiers like a Nazi salute and swastika were used in a few cartoons by Jari and Ranta. However, nativist and racist ideology often ignored Nazism as a signifier in Finnish cartoons, whereas nationalist symbols, such as the Finnish flag, were emphasised. Even in Ranta's cartoons, which were by far the most critical of PS in the Finnish context, the criticism was more often signified by associating it with nationalism and racism rather than Nazism - as it was in the sampled cartoon from 2011 in which MP Immonen is sent to a course on how to "hide your racism" by the party leader Soini (see Image 3).

\section{Image 3}

Signifying the domestic populist party with nativist and nationalist signifiers was very common also in Denmark, in which strict immigration policies have been in place for the whole of the $21 \mathrm{st}$ century, during which time DF has assisted the governing cabinet (see Rydgren, 2010). Most commonly, the cartoons criticized the nativist approach of DF that emphasises the special status of Denmark in comparison to other nation states or non-native ethnic groups. Typically, as seen in one 
cartoon drawn by Jens Hage in 2011, the leading figures of DF (e.g. Kjærsgaard and Thulesen Dahl) were portrayed as dogs that guard the Danish barbed-wire fence border from the EU and pee onto the other side of the border. In Danish cartoons, nationalism was often signified by the Danish red-white coloured flag being abused by the DF members. However, in some cartoons clear connections to racism were also made, as in Anne-Mette Steen Petersen's image from 2005, in which Kjærsgaard is depicted as a character in the children's card game "Old Maid (Black Peter)" wearing a red and white dress and dragging a black baby doll.

In all the countries, the caricatured politicians were also portrayed as "populists" in the sense that they differed from "serious" politicians because of their demagogic rhetoric or style. In some Finnish and Danish cartoons, this was signified, for example, by the megaphones populist politicians use when shouting their xenophobic message at "the people". In Swedish cartoons, the populist signification was clear in several images that placed SD leader Åkesson alongside other commonly identified European right-wing populist figures, such as Soini, Geert Wilders from the Netherlands, Marine Le Pen (Front National) from France, Nigel Farage (UKIP) from the UK and Hans-Christian Strache (FPÖ) from Austria. The clear statement was made in Jan-Erik Ander's cartoon, published in 2015, in which Åkesson and Le Pen are portrayed as marionettes manoeuvered by Vladimir Putin's funding - signified by the bundle of bank notes in his hand,suggesting that Putin is the real spin doctor of European right-wing populism.

However, some positive images of the domestic populist parties and their politicians were also published in Sweden and Finland during the first half of the 2010s. In Sweden, most of these cartoons were traditional caricatures of political leaders, such as Lennart Moberg's drawings of Jimmie Åkesson, indicating the increased societal status of these figures. Especially in Finland, some cartoons published in the leading daily Helsingin Sanomat and in the leading popular paper Ilta-Sanomat noticed the astonishing success of PS in the "big bang elections" of 2011 in a rather positive light. In these cartoons, the success of the party was signified, for example, by the 
increasing weight of the party leader Soini, by diagrams demonstrating the growth of PS at the expense of traditional mainstream parties or as beauty contests in which Soini succeeds. However, these kinds of images were exceptions among the Nordic cartoons portraying the domestic populist politicians. In general, the cartoons were critical of populist politicians where, especially in Denmark and Sweden, populism was often negatively connected to Nazism, Fascism, nativism and xenophobia. In general, the Danish cartoons highlighted the confrontation between pan-European openness and ethnic nationalism, whereas Swedish and Finnish cartoons emphasized the value conflict between the populist movement and other political players in their domestic political arena.

\section{Discussion}

The significations of populist actors in political cartoons reflect contextual differences in the images of the Nordic populist parties of the early 21st century (cf. Van Hecke, 2017, pp. 144-145). SD's representation as a movement trying to polish its shield but having "true roots" or a background in National Socialism enforces both fascist, racist and more neutral significations. In turn, PS, from 2010 to 2015 were a quite traditional populist protest movement linked to its predecessor the Finnish Rural Party (1959-1995), combining anti-elite appeal and demands for social equality with criticism of immigration, and were depicted more heterogeneously and occasionally even positively during their successful 2011 elections. Perhaps, most strikingly, DF was connected very visibly to Nazism and racism in Danish political cartoons between 2005 and 2010.

The result can be partly explained by the life cycle phases of the parties. DF lived its insurgent phase earlier than its Nordic counterparts in Finland and Sweden. Nor can one forget the impact of the Mohammed cartoon crisis in Denmark that "re-politicised the Danish press" (Esmark \& Ørsten, 2008, p. 40) and, as a kind of counter effect, increased the provocativeness of political cartoons in the name of freedom of speech (e.g. Eide et al., 2008). However, more recently DF has entered the “established phase” of a populist party's life cycle (see Stewart et al., 2003, pp. 221-223), proved by the fact that during the first parliamentary elections of the 2010s, the general media attention DF 
received was quite modest and "normalised" (Anonymized, 2017a). Furthermore, there were also far fewer large-scale political scandals linked to DF in Denmark than to SD in Sweden or PS in Finland between 2010 and 2015 (Anonymized, 2017c).

Thus, compared to the Swedish and Finnish right-wing populist parties, DF's long-term popularity and position as a party that assists the governing cabinet has normalised it within the Danish political arena in the 2010s. In addition, Danish political culture seems to be more "tolerant" of populism in its discourse than the Swedish or Finnish public is, which might partly explain the extremity of the Danish cartoons (cf. Esmark \& Ørsten, 2008, pp. 40-41). It can also be argued that the imagery associated with SD and PS might have recently changed as SD has gained popularity and become more mainstream, whereas PS has become a clearly radical, right-wing populist party with a nativist programme, although the sample of the study does not allow us to test that hypothesis. However, one can claim that the success and life cycle phase of a domestic populist party will correlate with the particular moral order of the context.

It is also obvious that not only do national contexts and political cultures affect cartoons, so do the differences between the individual cartoonists. This was evident in the Finnish case in which Ranta differed strikingly from other cartoonists with his critical stance of the domestic populist movement, whereas Karlsson presented a rather modest form of criticism (Anonymized, 2017b). The difference might be partly explained by the publications - Ranta's cartoons were published in Kirkko \& Kaupunki that highlights ethical discussions, whereas Karlsson's cartoons are published in Helsingin Sanomat, the largest and most established daily of Finland - but a more probable explanation is the cartoonists' different starting points in style and method. Therefore, the overrepresentation of Jan-Erik Anders' cartoons in the Swedish sample may bias the image of the Swedish case. Even if the Swedish media has generally been critical of SD and its approaches, only Anders portrayed SD in such a negative light in the sample. 
The two-fold nature of humour employed in political cartoons may also explain the result. It is widely known that various political statements can be made via humour far more easily than they can by serious and rational argumentation (Kuipers, 2012). Billig (2001), for example, has demonstrated how the extreme right has applied humour in its nativist and racist discourses to strengthen their group identity and to downplay criticism of these discourses. The liberal discourses in political cartoons can quite similarly benefit from humour and indicate alleged links (i.e. signifiers) between the extreme right and right-wing populist parties in a way that is not accepted, for example, in general political news discourse (cf. Van Hecke, 2017, p. 143).

\section{Conclusion}

The success of right-wing populist movements has shaken the formerly rather stable Nordic party system in the 21 st century. The conservative and nativist approach of these movements has broken the traditional separation of right and left blocs and emphasised norm and value confrontations, thus nurturing the imaginaries of political cartoonists. The rise of populist sentiment has created fertile ground for political satire, which is keen to focus on contemporary ideological confrontations and other contested areas. Therefore, an analysis of the signifiers depicting populism in political cartoons reveals how the moral order behind the social imaginaries of the Nordic countries in the 21 st century has been provocatively contested by right-wing populism (cf. Taylor, 2003).

In general, it seems that political cartoons emphasised the extremist right-wing features of the Nordic populist parties more than is common in news coverage (cf. Herkman, 2016; Anonymized, 2017a). The result might be biased due to the selected sampling method, but it is also understandable, since political cartoons tend to highlight the underlying tendencies and ideas of the given moment (Greenberg, 2002, p. 181; Hess \& Northrop, 2011, p. 20), constructing controversial political tensions by means of caricature (Abraham, 2009, p. 120; Navasky, 2013, p. 35). Thus, the cartoons indicated the insurgent phase of the populist parties by emphasizing liberal values and confronting these parties and linking the cartoons within the discourse of "watch-dog news media". 
The Nordic countries have been perhaps the most distinguished representatives of liberal democracies anywhere. The ideas of human rights, equality between the sexes and the rights of sexual, ethnic and religious minorities as well as freedom of speech have been pursued vigorously in all Nordic countries, Sweden has especially carried out rather generous immigration and refugee policies. However, right-wing populist movements have attacked all the values central to the liberal democracies of the Nordic region and then, in turn, they have been attacked by political cartoonists, who seem to strongly defend the liberal ethos as their core value.

The differences between the signifiers of populism in political cartoons echoed the differences in the particular populist parties and in political cultures. However, the links between the portrayal of populism and the life cycle phase of the domestic populist party suggest that as these parties become ever more mainstream, the moral order of liberal democracy might also change. Thus, the public discourse or tone around populism is softened and the satirical edge of the political cartoons seeks new targets and signifiers. In addition to helping populist movements establish themselves in the public eye, changes in the media environment may also help to explain the change in the moral order. In a contemporary "hybrid media system" (Chadwick, 2013) traditional news media is intertwined with online media and social media in multiple ways, and the populist's identity and community construction is essentially promoted through social media platforms (Krämer, 2017). Regarding current struggles surrounding moral order, it may be that political cartoons play only a minor role - mostly as an inspiration for debates and memes circulated in social media forums. Therefore, further studies are needed to ascertain whether populist parties enjoying electoral success have changed opinion discourses and altered their signification in the political cartoons of the late 2010s.

\section{References}


Abraham, L. (2009). Effectiveness of cartoons as a unique visual medium for orienting social issues. Journalism \& Communication Monographs, 11(2), 117-165.

Allern, E. H. (2013). The contemporary relationship of "new left" and "new right" parties with interest groups: exceptional of mainstream? The case of Norway's Socialist Left and Progress Party. Scandinavian Political Studies, 36(1), 67-90.

Arter, D. (2012). "Big bang” elections and party system change in Scandinavia: farewell to the enduring party system? Parliamentary Affairs, 65(4), 822-844.

Aslanidis, P. (2016). Is populism an ideology? A refutation and a new perspective. Political Studies, 64(IS), 88-104.

Baas, D. (2014). Bevara Sverige svenskt: ett reportage om Sverigedemokraterna. Stockholm: Bonnier.

Bal, A. S. (2011). Cartoons: when politics are too serious to be left to politicians. Introduction to the special issue, Cartoons and Political Marketing: Challenges in the Age of New Media. Journal of Public Affairs, 11(3), 135-136.

Bale, T., Kessel, S. van, \& Taggart, P. (2011). Thrown around with abandon? Popular understandings of populism as conveyed by the print media: a UK case study. Acta Politica, 46(2), $111-131$.

Berger, A. A. (1995). Blind men and elephants: perspectives on humor. New Brunswick: Transaction Publications.

Billig, M. (2001). Humour and hatred: the racist jokes of the Ku Klux Klan. Discourse \& Society, 12(3), 267-289.

Boomgaarden, H. G., \& Vliegenthart, R. (2007). Explaining the rise of anti-immigrant parties: The role of news media content. Electoral Studies, 26(2), 404-417. 
Bos, L., \& Brants, K. (2014). Populist rhetoric in politics and media: A longitudinal study of the Netherlands. European Journal of Communication, 29(6), 703-719.

Bos, L., Brug, W. van der, \& Vreese, C. de. (2011). How the media shape perceptions of right-wing populist leaders. Political Communication 28:2, 182-206.

Bruun, H. (2012). Political satire in Danish television: reinventing a tradition. Popular Communication, 10(1-2), 158-169.

Canovan, M. (2005). The People. Cambridge: Polity Press.

Canovan, M. (1999). Trust the people! Populism and the two faces of democracy. Political Studies, 47(1), 2-16.

Chadwick, A. (2013). The hybrid media system. Politics and power. Oxford: Oxford University Press.

Eide, E., Kunelius, R., \& Phillips, A. (Eds.). (2008). Transnational media events: the Mohammed cartoons and the imagined clash of civilizations. Göteborg: Nordicom.

Esmark, A., \& Ørsten, M. (2008). Media and politics in Denmark. In J. Strömbäck, M. Ørsten \& T. Aalberg (Eds.), Communicating politics: political communication in the Nordic countries (pp. 2543). Gotheburg: Nordicom.

Engesser, S., Ernst, N., Esser, F., \& Büchel, F. (2017). Populism and social media: how politicians spread fragmented ideology. Information, Communication \& Society, 20(8), 1109-1126.

Fryklund, B. (2015). Nordic Populism - changes over time and space. A comparative and retrospective analysis of populist parties in the Nordic countries from 1965 to 2015. Paper in XII European Sociological Association (ESA) conference, Prague, August. 
Greenberg, J. (2002). Framing and temporality in political cartoons: a critical analysis of visual news discourse. The Canadian Review of Sociology and Anthropology, 39(2), 181-198.

Herkman, J. (2016). Construction of populism: meanings given to populism in the Nordic press. Nordicom Review, 37(Special Issue), 147-161.

Hess, S., \& Northrop, S. (2011). American political cartoons: evolution of a national identity, 1754-2010. New Brunswick: Transaction Publishers.

Hollis-Touré, I. (2016). Introduction: risk assessing Charlie Hebdo. French Cultural Studies, 27(3), $219-222$.

Jagers, J., \& Walgrave, S. (2006). Populism as political communication style: an empirical study of political parties' discourse in Belgium. European Journal of Political Research, 46(3), 319-345. Jungar, A-C. (2016). From mainstream to the margin? The radicalisation of the True Finns. In T. Akkerman, S. L. de Lange \& M. Rooduijn (Eds.), Radical right-wing populist parties in Western Europe. Into the mainstream? (pp. 113-143). New York: Routledge.

Jungar, A-C., \& Jupskås, A. R. (2014). Populist radical right parties in the Nordic region: a new and distinct party family? Scandinavian Political Studies, 37(3), 215-238.

Krämer, B. (2017). Populist online practices: the function of the Internet in right-wing populism. Information, Communication \& Society, 20(9), 1293-1309.

Kuipers, G. (2011). The politics of humour in the public sphere: cartoons, power and modernity in the first transnational humour scandal. European Journal of Cultural Studies, 14(1), 63-80.

Laclau, E. (2005). On populist reason. London: Verso. 
Mazzoleni, G. (2014). Mediatization and political populism. In F. Esser \& J. Strömbäck (Eds.), Mediatization of politics: Understanding the transformation of Western Democracies (pp. 42-56). Hampshire: Palgrave Macmillan.

Mazzoleni, G., Stewart, J., \& Horsfield, B. (Eds.) (2003). The media and neo-populism: A contemporary comparative analysis. Westport, CT: Praeger.

Mesežnikov, G., Gyárfášova, O., \& Smilov, D. (2008). Populist politics and liberal democracy in Central and Eastern Europe. Bratislava: Institute for Public Affairs.

Moffit, B., \& Tormey, S. (2014). Rethinking populism: politics, mediatisation and political style. Political Studies, 62(2), 381-397.

Moriarty, S. (2005). Visual semiotics theory. In K. Smith, S. Moriarty, G. Barbatsis \& K. Kenney (Eds.), Handbook of visual communication: theory, methods, and media (pp. 227-241). Mahwah, New Jersey: LEA.

Mulkay, M. (1988). On humour: its nature and its place in modern society. Cambridge: Polity Press.

Mudde, C. (2007). Populist radical right parties in Europe. Cambridge: Cambridge University Press.

Mudde, C., \& Kaltwasser, C. R. (2012). Populism and (liberal) democracy: a framework for analysis. In C. Mudde \& C. R. Kaltwasser (Eds.), Populism in Europe and Americas: threat or corrective for democracy? (pp. 1-26). Cambridge: Cambridge University Press.

Navasky, V. S. (2013). The art of controversy: political cartoons and their enduring power. New York: Alfred A. Knopf.

Palmer, J. (1994). Taking humour seriously. New York: Routledge. 
Paloheimo, H. (2012). Populismi puoluejärjestelmän vedenjakajana. In S. Borg (Ed.), Muutosvaalit 2011 (pp. 324-344). Helsinki: Oikeusministeriö.

Pauwels, T. (2010). Explaining the success of neo-liberal populist parties: The case of Lijst Dedecker in Belgium. Political Studies, 58(5), 1009-1029.

Roodjuin, M. (2014). The mesmerising message: The diffusion of populism in public debates in Western European media. Political Studies, 62(4), 726-744.

Rose, G. (2001). Visual methodologies: an introduction to the interpretation of visual materials. London: Sage.

Rydgren, J. (2010). Radical right-wing populism in Denmark and Sweden: explaining party system change and stability. The SAIS Review of International Affairs, 30(1), 57-71.

Stanley, B. (2008). The thin ideology of populism. Journal of political ideologies, 13(1), 95-110.

Stewart, J., Mazzoleni, G., \& Horsfield, B. (2003). Conclusion: Power to the media managers. In G. Mazzoleni, J. Stewart \& B. Horsfield (Eds.), The media and neo-populism: A contemporary comparative analysis (pp. 217-236). Westport: Praeger.

Taggart, P. (2000). Populism. Buckingham: Open University Press.

Taylor, C. (2003). Modern social imaginaries. Durham: Duke University Press.

Van Hecke, M. (2017). Imag(in)ing the eurocrisis: a comparative analysis of political cartoons. National Identities, 19(1), 129-147.

Widfeldt, A. (2010). Högerpopulismen: ett växande politiskt fenomen. In J. Ekman \& J. Linde (Eds.), Politik, protest, populism - deltagande på nya villkor (pp. 158-181). Malmö: Liber.

Wiid, R., Leyland, P. F., \& Engstrom, A. (2011). Not so sexy: public opinion of political sex scandals as reflected in political cartoons. Journal of Public Affairs, 11(3), 137-147. 